Environment Conservation Journal 20 (1\&2) 47-50, 2019

ISSN 0972-3099 (Print) 2278-5124 (Online)

Abstracted and Indexed

\title{
Role of viddha-agnikarma in chronic plantar fasciitis- A Case Study
}

\author{
Yadav P. $\bowtie$ and Shukla D.
}

Received: 29.06 .2018

Revised: 28.10.2018

Accepted: 12.02.2019

\begin{abstract}
Chronic plantar fasciitis is a common condition that causes pain under the heel particularly during walking. Sometimes a bony spur may be seen at the attachment of the plantar fascia. Pain associated with this condition may cause substantial disability and poor health related quality of life. Those affected can also have significant limitations in daily routine activities. The prevalence and prognosis are unclear but found in patients of middle aged groups. It is more often seen in men between 40 to 60 years of age. Treatment with analgesics, use of heel-pad and steroids injection but they do not give permanent cure for the disease and have side effects, complications and are costly to afford by common man. Vatakantaka described by Acharya Sushruta has similar symptoms as of plantar fasciitis. Vatakantaka is Snayu Asthi Sandhi ashrita so should be treated on the similar line of treatment and can effectively be managed with Agnikarma. In this study a case of chronic plantar fasciitis was treated by Viddha-agnikarma which gave satisfactory results.
\end{abstract}

Key words: Chronic plantar fasciitis, Viddha-agnikarma, Heel pain, Vatakantaka.

\section{Introduction}

Plantar fasciitis is a common cause of heel pain that occurs due to inflammation of the plantar aponeurosis at its attachment on the tuberosity of the calcaneum (Maheshwari, 2002). Chronic plantar fasciitis is found in patients of middle aged groups. This is often known as policeman's heel (Das, 2018). The exact pathology of chronic plantar fasciitis is largely unknown but the condition is more often seen in men between 40 to 60 years of age who are more prone to wear ill-fitting shoes. The prevalence and prognosis of this condition are unclear but in most people the symptoms may resolve over time (Landorf, 2015). The pain is first complaint which is worst early in the morning associated with stiffness, restricted movement and tenderness below the calcaneus. The symptoms gradually improve with activity. On examination, marked tenderness is found over the medial aspect of the calcaneal tuberosity at the site of attachment of the plantar fasciitis. X-ray may show a sharp bony spur projecting forwards from the tuberosity of the calcaneum. Its significance is doubtful as it may not be the cause of painful heel and may be a simple association. Treatment with analgesics and

\section{Author's Address}

Department of Shalya tantra, Uttarakhand Ayurved University, Gurukul Campus, Haridwar, India

E-mail.: dr.priti.yadav01@gmail.com use of a heel-pad, local induction of steroids brings relief in most cases but they do not give permanent cure for the disease and have side effects, complications and are costly to afford by common man. Acharya Sushruta has mentioned a condition i.e. Vatakantaka in Sushruta samhita which is caused by vitiated Vata dosha and it resembles to plantar fasciitis. It occurs due to constant standing and walking on uneven surface resulting into heel pain. Vatakantaka is snayu asthi sandhi ashrit and has to be treated with Oleation, Poultice, Agnikarma, bandaging and massage (Samhita sushruta, 2016). In Ashtang Hridayam Acharya Vagbhatta mentioned that due to excessive exertion and walking on uneven surface which causes vitiation of Vata Dosha resulting in pain in Gulpha (Hridayam Ashtang, 2016; Ebnezar, 2003). Keeping this in mind, a case study of Viddhaagnikarma in management of chronic plantar fasciitis was selected.

\section{Pathophysiology}

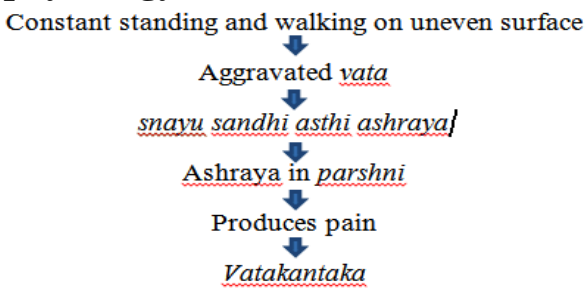




\section{Case report}

A case of 43 years old female patient who was a housewife visited to OPD of Shalya tantra department of Gurukul campus, UAU, Haridwar with complaints of painful heel, early morning stiffness, tenderness in both heels and restricted movements for three months showing no improvements with previous conservative treatments. Her maximum perceived pain intensity was 7 on visual analog scale (range 0 to 10) at the time of presentation. All investigations like routine blood investigation and X-ray examination of heel were found normal. After proper examination patient was diagnosed with non-specific chronic plantar fasciitis.

\section{Treatment plan}

After careful assessment it was decided to treat the condition with Viddha-agnikarma at an interval of seven days along with conservative treatment.

Materials required

Insulin needles (26 no.)
1. Sterile gauze

2. Lighter

3. Surgical spirit

4. Betadiene solution

5. Sponge holding forceps

6. Ghritkumari swaras

7. Jatyadi ghrita

\section{Procedure of Viddha-agnikarma}

After taking informed written consent skin of the area to be needled was thoroughly cleaned with betadiene solution and spirit respectively. Insulin needle of 26 no. sizes were heated till red hot with the help of lighter and inserted at the points of maximum tenderness. After 2-4 sec needles were taken out of the skin and were discarded. The needles must be discarded after every single use. The procedure of viddha-agnikarma is shown in pictures figure 1 . It is to be noted that a proper space between insertions of needles should be kept. This procedure was repeated 3 times at the interval of 7 days.
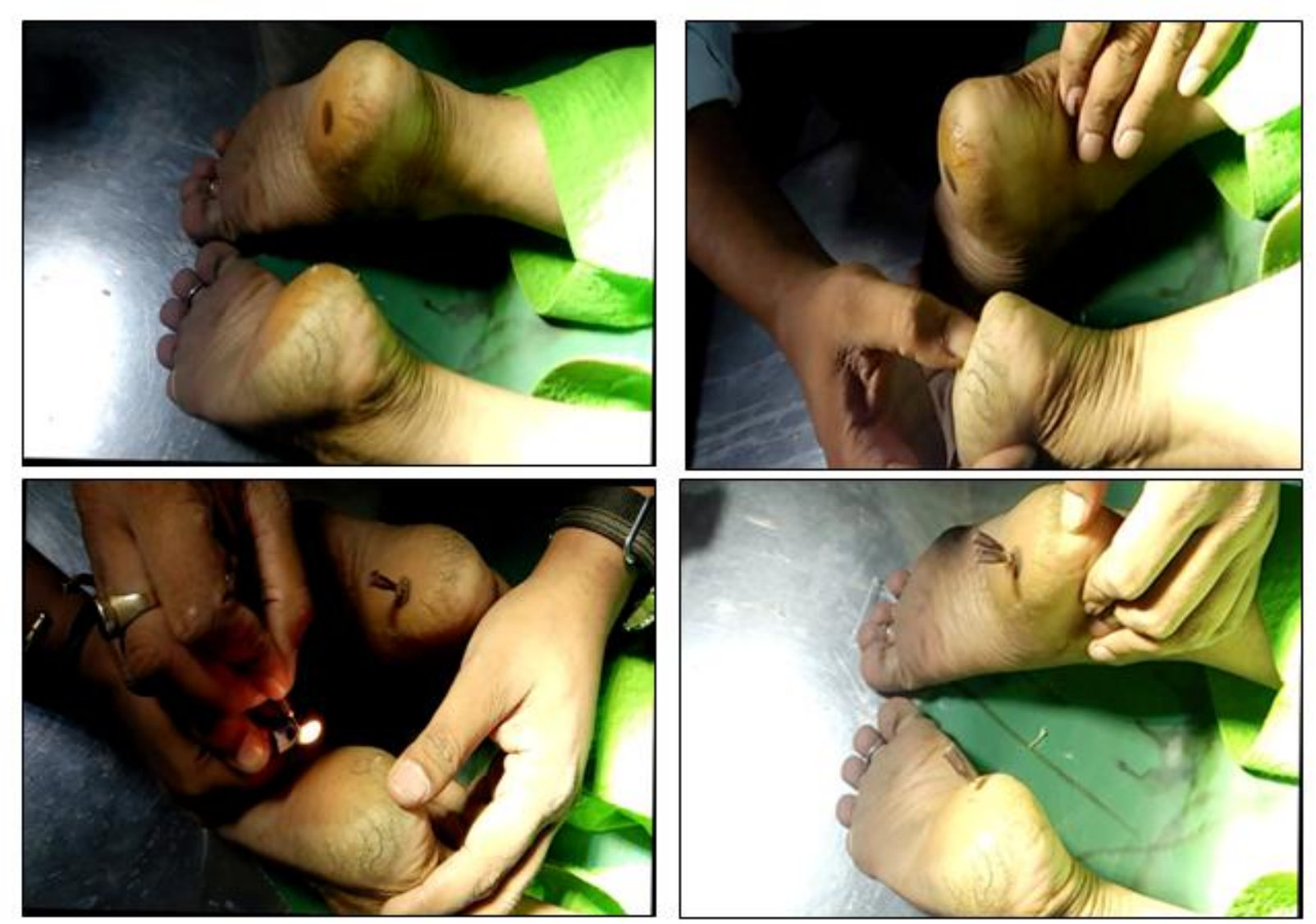

Figure 1.showing procedure of viddha-agnikarma 


\section{Probable mode of Action}

In viddha-agnikarma the therapeutic heat is transferred to skin and gradually to deeper structure with the help of red hot needle which eventually pacifies Vata dosha and gives relief in pain resulting in improved restricted movements.

\section{Assessment criteria}

The severity of symptoms in the patient are assessed subjectively as per grading from 0 to 3 ( 0 = no symptom, $1=$ mild, $2=$ moderate, $3=$ severe) which has been shown in table 1 .

Table 1. Assessment of severity of symptoms

\begin{tabular}{|l|c|}
\hline Severity of symptoms & Grading \\
\hline No symptoms & 0 \\
\hline Mild & 1 \\
\hline Moderate & 2 \\
\hline Severe & 3 \\
\hline
\end{tabular}

The pain intensity was assessed with visual analogue scale (VAS) scoring system pretreatment, during and after treatment. This pain assessment tool is marked from no pain (0) at one end to pain as worst as it could possibly be (10) at the other end as shown in figure 2 .

\section{Results and Discussion}

After $1^{\text {st }}$ sitting, patient got much improvement and her pain intensity was 4 on VAS. There was found marked improvement in other symptoms also after $2^{\text {nd }}$ sitting and VAS score was 2 . After $3^{\text {rd }}$ sitting the pain had been completely eliminated (VAS score $=$ 0 ). The therapeutic effect of vidhha-agnikarma on cardinal symptoms of the disease has been shown in table 2 and also represented on bar diagram (fig. 3). Patient was fully satisfied with Viddhaagnikarma Chikitsa.

Chronic Plantar fasciitis can occur due to walking on uneven surface and wearing ill-fitting shoes which causes repeated injury to the plantar fascia results in painful heel. It is a common cause of heel pain and discomfort affecting the health and quality of life of patients (Landorf, 2015). According to Ayurveda pain occur due to vitiation of Vata dosha and Agni has vata shamaka properties like Ushna, Tikshna, Sukshma, thus helpful in relieving pain in heel. After Agnikarma vasodilatation occur on affected site due to its Sanchari Guna resulting in decrease in stiffness (Shekokar et al., 2016). After relieving all the above symptoms movement was also improved.

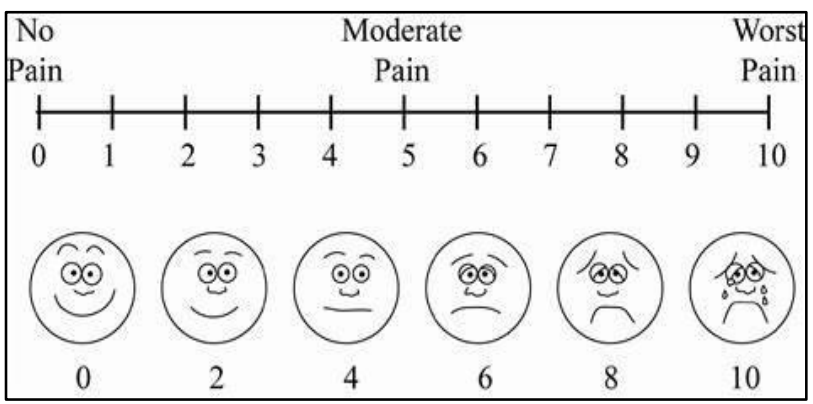

Figure 2. Visual analogue scale

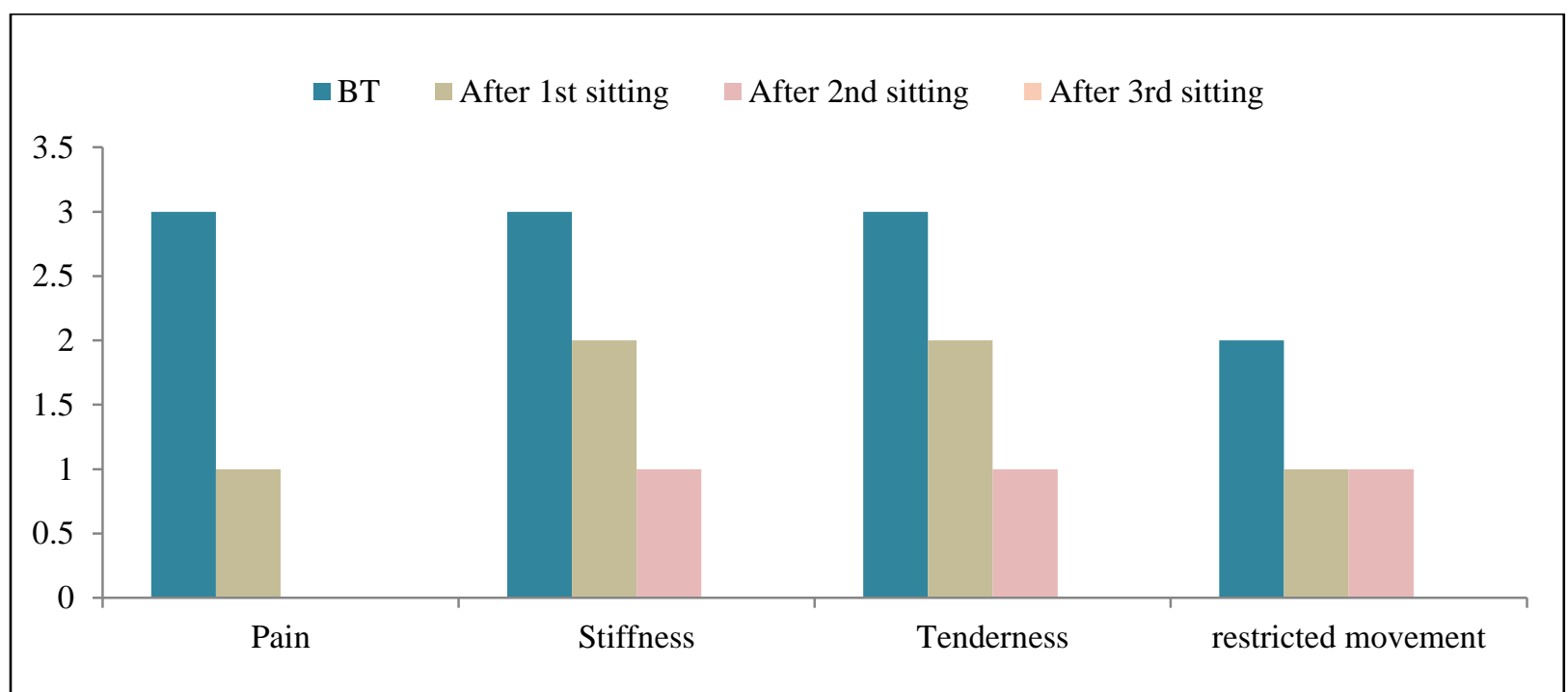

Figure 3.Therapeutic effect of procedure as per cardinal symptoms of disease 
Yadav and Shukla

Table 2. Therapeutic effects on cardinal symptoms of Vatakantaka

\begin{tabular}{|c|c|c|c|c|}
\hline Symptoms & $\begin{array}{c}\text { Before } \\
\text { treatment }\end{array}$ & $\begin{array}{c}\text { After 1 } \\
\text { sitting }\end{array}$ & $\begin{array}{c}\text { After 2 } \\
\text { sitting }\end{array}$ & $\begin{array}{c}\text { After 3 }^{\text {rd }} \\
\text { sitting }\end{array}$ \\
\hline Vedana (Heel pain) & 3 & 1 & 0 & 0 \\
\hline Stambha (stiffness) & 3 & 2 & 1 & 0 \\
\hline Sparshasahatva (Tenderness) & 3 & 2 & 1 & 0 \\
\hline Kriyahani (restricted movements) & 2 & 1 & 1 & 0 \\
\hline
\end{tabular}

\section{Conclusion}

Follwing conclusion can be drawn from the above study-

1. Viddha-agnikarma is a non-invasive treatment modality and can be done as OPD procedure.

2. Agnikarma gives immediate relief in pain hence beneficial for women to perform their daily household activities.

3. It is cost effective and safe therapeutic regimen for plantar fasciitis.

4. The time required for the whole procedure is very less.

5. Number of sittings depends upon chronicity and severity of the disease.

\section{References}

Das S, 2018. A concise textbook of Surgery, 10th edition Kolkata: S. Das publication: 380.

Ebnezar John, 2003. Text book of Orthopaedics $2^{\text {nd }}$ edition New Delhi: Jaypee Brothers Medical Publishers: 225.
Maheshwari J., 2002 Essential Orthopaedics, $3^{\text {rd }}$ Edition New Delhi : Mehta publishers: 259.

Samhita Sushruta, 2016. dr. K. K. Thakral nidana sthana chapter 1, Varanasi Chaukhamba Orientalia: 705.

Samhita sushruta, 2016. dr. K. K. Thakral chikitsa sthana chapter 4, Varanasi Chaukhamba Orientalia: 234.

Hridayam ashtang, 2016. Kaviraja Atrideva Gupta nidana sthana chapter 15 Varanasi Chaukhamba Prakashan: 380.

Samhita Charak, 1994. Vaidya Yadavji Trikamji acharya sutrasthana chapter 14 Varanasi Chaukhamba Sanskrit sansthan: 89.

Samhita Sharangadhar, $4^{\text {th }}$ edition Varanasi, Chaukhamba orientalia: 135 .

Bhaishajya ratnavali, 2002. Govind Das $16^{\text {th }}$ edition Varanasi, Chaukhamba Sanskrit samsthan: 374.

Landorf K. B. 2015. Plantar heel pain and plantar fasciitis pii: 1111. [PMC free article] [PubMed] [Google Scholar]

Shekokar Anantkumar V, Borkar Kanchan M, Patle Rajani, 2016. To Study the Efficacy of Agnikarma in Vatakantaka w.s.r. to Plantar fasciitis Ayushdhara, 3(6): 919-928. 